\title{
Perceived Effects of Resource-Use Conflicts on Rural Women Farmers in South-east Agro-Ecological Zone of Nigeria
}

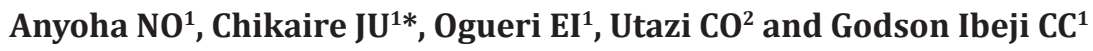 \\ ${ }^{1}$ Department of Agricultural Extension, Federal University of Technology, Owerri, Nigeria \\ ${ }^{2}$ Department of Agricultural Management and Extension Technology, Imo State Polytechnic, Nigeria
}

Received: 䟧June 26, 2018; Published: 眥July 05, 2018

*Corresponding author: Chikaire JU, Department of Agricultural Extension, Federal University of Technology, Owerri, Nigeria

\begin{abstract}
This study analyzed specifically the effects of resource-use conflict especially, land on rural women farmers in Southeast, Nigeria. .A total of 300 rural women farmers were purposively selected from 3 states in southeast where conflicts have occurred. Data collected were analyzed descriptively-using percentages, mean and standard deviation. Results got showed that farmerfarmer conflicts, pastoralists- farmer conflicts and communal conflicts were predominant in the study area with $100 \%$ response. The major causes of resource use conflicts were increasing population $(M=3.37)$, overgrazing of farmland $(M=3.35)$, breakdown of moral economy ( $M=3.57)$, pollution of water $(M=3.46)$, among others. The effects on women included reduced crop yields ( $M=3.37)$, burning of crops $(\mathrm{M}=3.38)$, reduced farm, reduced income $(\mathrm{M}=3.01)$, loss of human lives $(\mathrm{M}=3.56)$, rape/abduction of women $(M=3.00)$, hatred $(M=2.63)$, fear $(M=2.57)$, widowhood $(M=2.93)$ among others. The following strategies were identified, giving financial assistance to victims ( $M=2.65)$, creating job opportunities $(M=2.53)$, proper land use planning $(M=2.63)$, compensation to land owner $(\mathrm{M}=3.67)$. These farmers could be helped provision of credt facilities and proper land use planning programme.
\end{abstract}

Keywords: Conflicts; Farmers; Agriculture; Health; Women

\section{Introduction}

Worldwide, land remains an important natural capital for every nation and individuals, and because of this, it's not unusual that there is land conflict across the world, especially in developing nations where a huge population depends on agriculture for their livelihood [1]. Land-related conflicts are increasingly becoming a threat to rural economic activities such as agriculture in most subSaharan African countries [2,3]. The prevalence of these conflicts is escalating at a time when crop yields are stagnant or even declining for some countries in the region [4]. It is therefore apparent that, as governments grapple to enhance technology adoption and revamp the agriculture sector's performance to meet the high and increasing demand for food, land tenure security becomes crucial in attaining this goal [5].

In most African countries, land conflict commonly arise at the countries' boarder level, district boarder, among ethnic groups, in the community over common land, between individuals over boundary [6]. Land conflict between individuals is the most common type of conflict in the rural community, and yet in many cases, conflict at this level lacked sufficient attention from the authority. On the other hand, countries' boarder conflict, district and inter-ethnic land conflict received major response, which tends to result into immediate solution due to political dimension involved [6]. Because of lack of attention by the authorities over land conflict at the rural community, some vulnerable people like women and orphans have continued to lose their rights to land to the greedy people. Some people have lost their lives due to land fight and some incidences of land conflict creates hatreds among the parties involved which goes on from generation to another. Moreover, the individuals who lose their rights to land due to conflict find themselves in deep poverty, due to decline in productivity, food insecurity and a fall on the income level. The increase in the incidences of land conflict in Africa is largely being attributed to the failure of existing land tenure systems to address the challenges 
that hinders use of land in more effective way, which would permit investment and enhance productivity ref. The struggle for land is also being exacerbated by increase in population, resource scarcity and other factors like technological change, improved terms of trade for agriculture and demand for land for non-agricultural use [7] also looked at exclusion and relative deprivation as major cause of conflict in Africa.

Nigeria has experienced conflicts of grave proportions among several ethnic and religious communities in different regions and states. In the far north, for instance, a conflict of religious nature continues to break out at locations like Kano, Katsina, Zaria and Kaduna, and more recently, Maiduguri among other places [8]. In the Southwest there were violent communal conflicts at Sagamu, Lagos, Ife -Modakeke, etc. In the South-East, the Umuleri-Aguleri conflicts were most noticeable. The communal and oil-induced conflicts in the Niger Delta also increased in scope and intensity [9]. However, a research conducted by Elaigwu (2005) confirms that some states in the Northern Nigeria have experienced one or more ethno-religious conflicts except Kogi and Zamfara States. These conflicts have adversely affected the country's development and security.

Land is probably the most important resource needed by man for his day-to-day existence. All human livelihoods and activities are directly or indirectly dependent on land at varying thresholds [8] Land connotes different meanings to the various user groups. For instance, builders, manufacturers, fishermen, miners, hunters and farmers have different specifications in their requirement for land for their production/services. Out of all user-groups, agricultural production perhaps exhibits the highest form of sophistication in its use of land [10]. Not only must agricultural land be capable of supplying crop-specific nutrient and water; soil temperature, structure, texture and $\mathrm{pH}$ levels are inevitable requisites in the choice of land for agricultural production activities; yet, land is a limited, somewhat scarce resource with natural access and usage barriers.

These factors of specifications, multifarious uses of land and its limitedness have necessitated that various shades of competition for its utilization must ensue. Thus, competition for land between and within various user groups has been the bane of mankind since time immemorial. Non-agricultural user groups compete with agricultural user groups on one hand, while there are various levels of intra user -group competition on the other hand. Indeed competition for land use is becoming keener and fiercer, largely due to increasing human and animal populations [11]. It has been illustrated that increasing population growth rate has continued to exert great pressure on available land resources with varying environmental and socio-economic implications [12-14].

Farmer-herdsmen conflict has remained the most preponderant resource-use conflict in Nigeria $[15,16]$. The necessity to provide food of crop and animal origin, as well as raw materials for industry and export in order to meet ever-growing demands, has led to both intensification and intensification of land use [17]. The competition of these two agricultural land user-groups, however, has often times turned into serious overt and covert manifestation of hostilities and social friction in many parts of Nigeria. The conflicts have demonstrated high potential to exacerbate the insecurity and food crisis particularly in rural communities where most of the conflicts are localized, with reverberating consequences nationwide.

Ajuwon [15] reported farmer - herdsmen conflict in Imo State, Southeast Nigeria. He noted that between 1996-2003, nineteen (19) people died and forty two (42) people injured in this rising incident of farmers-herders conflicts and the violence that often accompanies such conflict is an issue that can be regarded as being of national concern [15]. These conflicts were threats to both peace and national stability. Again, in a study carried out in Nigeria's Guinea Savannah, Fiki \& Lee [14] reported that out of 150 households interviewed, 22 reported loss of a whole farm of standing crops, 41 reported losses of livestock, while eight households from either sides reported loss of human lives. Their study also indicated that stores, barns, residences and household items were destroyed in many of the violent clashes. Serious health hazards are also introduced when cattle are made to use water bodies that serve rural communities.

\section{Statement of the Problem}

The effects of conflicts world over have been documented in scholarly literature. These include death, displacement, health, and education [18]. In the view of Yahaya [19] conflict disrupts markets, banking, and credit systems. In the absence of all these facilities life becomes unbearable for the society at large but women and children face the consequences more than men because of cultural roles assign to them. Nevertheless, even when exposure to actual armed violence is limited, the effects in terms of loss of security, income and service access, displacement, and other such phenomena are considerable. Notwithstanding this, little attention have been given to the socio-economic, health and psychosocial effects of land conflict on women in Southeast states of Nigeria where land conflicts of different categories have occurred. It is in line with this that this paper sought to examine the socio-economic effects of land conflict on women and children in the three southeast states namely Abia, Imo, and Enugu. The general objective of the paper is to examine the socio-economic effects of land conflict on women and children in the study states. The specific objectives were to

a) Identify the various forms/types of conflicts in the study states.

b) Ascertain perceived causes of land-related conflicts in the areas.

c) Describe effects of land-related conflicts on agricultural 
production, health and psychosocial well-being of the respondents and

d) Identify strategies for cushioning the effects land-related conflicts on the respondents.

\section{Methodology}

This study was conducted in southeast agro-ecological zone of Nigeria, characterized by tropical rainforest. The Southeast agroecological zone lies within latitudes $50 \mathrm{~N}$ to $60 \mathrm{~N}$ of the equator and longitudes $6 \mathrm{oE}$ and $8 \mathrm{oE}$ of the Greenwich meridian. Southeast Nigeria is made up of five (5) states-Abia, Anambra, Ebonyi, Enugu and Imo. The zone occupies a total land mass of about 10, 952, 400 hectares with a population figure of 17, 381, 729 person in 2016 projected from 2006 National Population Commission Census figure [20]. The multi-stage (4-stage) sampling technique was adopted in the process of sample selection. The first stage was the purposive selection of three states from the Southeast agro ecological zone, where cases of conflicts including farmer-pastoralists conflicts have occurred and were reported. Here, Abia, Enugu and Imo States were selected since conflicts occurrences have been recorded and reported widely.

Again, Enugu was selected because it is the gateway through which the nomads enter southeast from the North-central, settle and graze before moving to the other states of the Southeast. The second stage involved the purposive selection of the Local Government Areas where these conflicts occurred. In Abia State, two Local Government Areas were selected, namely Umunneochi and Ugwunagbo Areas. In Enugu, Uzo-uwani, Nkanu West and Udi Local Government Areas were also selected for the study, while in Imo State, Ohaji/Egbema, Owerri West, and Okigwe Local Government Areas were chosen as well.

The third involved the purposive selection of the communities in the Local Government Areas, where conflicts between crop farmers and pastoralists have occurred. In Abia, Isuochi and Lokpanta communities were chosen from Umunneochi Area, while Uturu was selected from Ugwunagbo Area. From Enugu State, Nimbo (Uzo-uwani), Ishi-ozalla (Nkanu West) and Ogui-Agueke (Udi) communities were chosen from the three Local Government Areas. From Imo State, Awarra and Umuapu (Ohaji/Egbema), Irete (Owerri West) and Ihube (Okigwe) communities were selected. The fourth stage involved the proportionate selection of 105 crop farmers from a total of 1050 affected farmers from Abia state, 69 crop farmers from a total of 695 crop farmers from Enugu state and a selection of 126 affected crop farmers from a total of 1260 affected farmers from Imo state.

This gave a total sample size of 300 crop farmers selected from the household lists of 3,005 crop farmers affected by the conflicts obtained and compiled by various agencies of the three States (Office of the Governor on Peace and Conflict Resolution;
Local Government and Chieftaincy affairs). The primary data were collected through questionnaire (survey), observation, and interview schedule. The data were collected from women farmers only. The secondary data were obtained from publications, such as research reports, academic journal and conference proceedings found relevant to this study. Descriptive statistical tools such as percentages presented in frequency distribution tables, bar chart, mean and standard deviation were used to achieve. Mean was computed on a 4-point Likert type rating scale of strongly agree, agree, disagree and strongly disagree assigned weight of 4,3,2,1 to capture the perceived causes of the conflicts.

The values were added and divided by 4 to get the discriminating mean value of 2.5. Any mean value equal to or above 2.5 was regarded as a major factor causing conflict, while values less than 2.5 were regarded as minor factors. Mean was also computed on a 3-point Likert type rating scale of major effect, minor effects, and no effect assigned weight of 3,2,1 to capture the perceived effects of land-related conflicts on the respondents. The values were added and divided by 3 to get the discriminating mean value of 2.0. Any mean value equal to or above 2.0 was regarded as major factor effects of land-related conflict, while values less than 2.0 were regarded as no effects. Mean was computed on a 4-point Likert type rating scale of strongly agree, agree, disagree and strongly disagree assigned weight of 4,3,2,1 to capture the perceived strategies to cushion the effects of land-related conflicts (objective 4). The values were added and divided by 4 to get the discriminating mean value of 2.5. Any mean value equal to or above 2.5 was regarded as a major strategy for cushioning effects of land-related conflict, while values less than 2.5 were not regarded as strategies.

\section{Results and Discussion}

\section{Types/dimensions of Conflicts in study states}

Table 1: Types/dimensions of Conflicts in study states Field survey, 2016.

\begin{tabular}{|c|c|c|}
\hline Conflict types & Frequency & Percentage \\
\hline Farmer - farmer conflicts & 300 & 100 \\
\hline Farmer - conservationist conflicts & 10 & 3.3 \\
\hline Pastoralists - conservationist conflicts & 0 & 0 \\
\hline Pastoralists - fishermen conflicts & 53 & 17.6 \\
\hline Pastoralists - fishermen conflicts & 300 & 100 \\
\hline Communal conflicts & 300 & 100 \\
\hline Religious conflicts & 110 & 36.6 \\
\hline Political/civil unrest/disturbances & 64 & 21.3 \\
\hline
\end{tabular}

Table 1 showed that the respondents have witnessed conflicts of different dimensions in the study area. The commonest being communal conflicts, farmer-farmer conflicts and pastoralists-crop 
farmer's conflicts (100\%). These 3 types of conflicts are regularly occurring in the study with grave consequences on individuals living. The 3 types of conflicts identified are mostly occasioned by land use competition and control. Other forms of conflicts were religious conflicts (36.6\%), political/civil unrest/disturbances (21.3\%) and farmer-conservationists conflicts (3.3\%) which occur in forest reserves and settlements where farmers fell trees for staking yam and homestead buildings. According to Mohamed and Ventura (2000 conflict on land and other natural resources can be a result of disputes within one or among several communities, such as boundary dispute between the community and outsiders, boundary dispute between members of the community, resource use dispute between community and outsiders, resource use dispute between community members, land use dispute between community and outsiders as well as land use dispute between community members. This means that conflicts inland uses and other natural resources are typically associated with opposing interests over the type of land use, limited access and use rights, unclear ownership and property rights, and the delineation of boundaries.

\section{Perceived causes of land-related conflicts in the study states}

Table 2: Causes of land-related conflicts, Field survey, 2016 Mean=2.50 above were major causes.

\begin{tabular}{|c|c|c|}
\hline Causes & Mean & SD \\
\hline Increasing population & 3.43 & 0.932 \\
\hline Loss of respect for culture & 2.76 & 0.751 \\
\hline Breakdown of moral economy & 3.57 & 0.638 \\
\hline Encroachment without permission & 3.3 & 0.984 \\
\hline Disregard for traditional authority & 2.85 & 1.021 \\
\hline Increasing needs/marginalization & 3.76 & 1.155 \\
\hline Theft of farm produce & 2.68 & 1.239 \\
\hline Land tenure issues & 3.28 & 0.608 \\
\hline Tress-passing boundary markers & 2.86 & 0.382 \\
\hline Overgrazing of farm land & 3.35 & 0.757 \\
\hline Pollution of water sources & 3.46 & 0.695 \\
\hline Land grabbing & 3.38 & 0.655 \\
\hline Scarcity of land & 3.03 & 1.054 \\
\hline Inheritanceproblems & 3.56 & 0.774 \\
\hline Overlapping ownership & 3.42 & 0.632 \\
\hline Fragmented land & 2.61 & 0.875 \\
\hline Low awareness of stock routes & 3.1 & 0.952 \\
\hline Disobedience of tenancy rules & 3.4 & 0.712 \\
\hline Orchestration of climate change & 2.62 & 0.552 \\
\hline Sexual harassment of women/girls & 2.86 & 0.787 \\
\hline Destruction of crops by animals & 3.04 & 1.252 \\
\hline Impunity in use of land resources & 3.56 & 1.574 \\
\hline Political instability/insensitivity & 2.78 & 0.564 \\
\hline Loss of tradition relationship & 3.08 & 0.744 \\
\hline
\end{tabular}

Table 2 showed the distribution of respondents by their perceived causes of land-related conflicts. Based on a discriminating index of 2.50, the causes of land-related conflicts were varied and many. They are increasing population with a mean response 3.43, loss of respect for culture $(\mathrm{M}=2.76)$, breakdown of moral economy $(M=3.57)$, encroachment without permission $(M=3.30)$, land tenure issues $(M=3.28)$, trespassing boundary markers $(M=3.35)$, land grabbing $(M=3.38)$, scarcity of land $(M=3.03)$, inheritance problems ( $M=3.56)$, overlapping ownership ( $M=3.42)$, fragmented landholdings $(\mathrm{M}=2.61)$, disobedience of tenancy rules $(\mathrm{M}=3.40)$, and loss of traditional relationship $(M=3.08)$. These are major causes of land - related conflicts when those involved are all crop farmers.

Again, when pastoralists are involved the following are possible causes conflicts, theft of farm produce for poverty alleviation by pastoralists $(M=2.68)$, pollution of water sources $(M=3.46)$, this happens when cattle defecate on rivers/streams, regarding land as common property $(M=3.10)$, sexual harassment of women and girls $(M=2.85)$, and destruction of crops by animals $(M=3.04)$. Other causes of land related conflicts could be climate change issues $(M=2.62)$ which affects the distribution of natural resources such as water and grasses, increasing needs for land and marginalization $(M=3.76)$. Again, political instability/insensitivity $(M=2.78)$ could also cause conflicts when there is change in policies of government and when the government cannot live up to its responsibility in protecting the citizenry.

When resources are scarce or abundant, political instability makes countries much more vulnerable to conflict. Instability impacts not only the governance structure, but also all other infrastructures that depend on government control and oversight, such as the banking system, national oil-production facilities, highways and ports. Population growth, environmental degradation, and resource inequality can combine to weaken an already unstable government's capacity to address the needs of the populace and thus fuel conflicts. And abundance of natural resources can provide the incentive for increased conflict over control of the incomegenerating sources [21].

Furthermore, political conflicts that turn violent often result in destruction of the environment and infrastructure that increases the scarcity of resources, which in turn increases the potential for violent conflicts over the scarce resources. Conflicts often damage infrastructure, such as pipelines or oil fields, and decrease productivity of mining, thus furthering the downward spiral in economies affected by conflict. In addition, poor management and oversight resulting from political instability accelerate the economic decline.

\section{Perceived effects of land-related conflicts on agricultural production of respondents}


Table 3: Perceived effects of land-related conflicts on Agricultural Production,Field survey, 2016 mean score 2.50 above are major effects.

\begin{tabular}{|c|c|c|}
\hline Effects on Agriculture & Mean & SD \\
\hline Reduced crop yield/productivity & 3.37 & 0.816 \\
\hline Burning of crops in field & 3.38 & 0.64 \\
\hline Stealing of farm produce & 3.31 & 0.484 \\
\hline Inadequate food for the family & 2.68 & 0.858 \\
\hline Reduced farm income & 3.01 & 0.902 \\
\hline Land redundancy & 3.56 & 0.648 \\
\hline Unable to repay debts and loans & 3.65 & 0.6 \\
\hline Missing of planting season & 3.22 & 0.579 \\
\hline Poor harvest & 3.55 & 0.765 \\
\hline Loss of capital investment & 2.9 & 0.981 \\
\hline Migration/lossoffarm labour & 3.48 & 0.811 \\
\hline Farmers turn refugees & 3.5 & 0.738 \\
\hline Scarcity of food items & 3.55 & 0.785 \\
\hline Denial/loss of land right & 3 & 0.507 \\
\hline Loss of human lives & 3.56 & 0.516 \\
\hline Loss of houses and properties & 2.54 & 0.604 \\
\hline $\begin{array}{l}\text { Reduction in the quality of } \\
\text { farmproduce/animal products }\end{array}$ & 2.91 & 0.903 \\
\hline $\begin{array}{l}\text { Loss of stored produce/livestock } \\
\text { product }\end{array}$ & 3.13 & 0.678 \\
\hline Reduced access to farm resources & 3.24 & 0.556 \\
\hline Loss of access to firewood collection & 3.43 & 0.742 \\
\hline $\begin{array}{l}\text { Reduction in quantity of food crop/ } \\
\text { animal product }\end{array}$ & 3.35 & 0.662 \\
\hline Loss of food sources & 3.56 & 0.638 \\
\hline Engagement in non-farm activities & 3 & 0.735 \\
\hline
\end{tabular}

Table 3 showed that all the respondents suffered the consequences of land-related conflicts as it touched their livelihood activity-agricultural production. The effects of the conflicts on agricultural production were reduced crop yield/ productivity ( $\mathrm{M}=3.37)$, burning of crops in field $(\mathrm{M}=3.8)$, stealing of farm produce $(M=3.31)$, inadequate food for the family $(M=2.68)$, reduced farm income $(M=3.01)$, land redundancy/abandonment $(M=3.56)$, unable to pay debts and loans $(M=3.65)$, missing of planting seasons $(M=3.22)$, poor harvests $(M=3.55)$, loss of capital investments $(M=2.90)$, migration/loss of farm labour $(M=3.48)$, farmers turn refugees $(M=3.50)$, denial of land rights $(M=3.00)$, loss of human lives $(\mathrm{M}=3.56)$, loss of houses and property $(\mathrm{M}=$ $2.54)$, reduction in the quality of farm produce $(M=2.91)$, loss of stored produce/livestock products $(M=3.13)$, reduced access to farm resources $(M=3.43)$, loss of access to firewood collection $(M=3.43)$, reduction in quantity of food for human consumption $(M=3.35)$, loss of food sources $(M=3.56)$ and engagement in nonfarm activities $(M=3.00)$.

Since rural community, rely on their produce mainly for home consumption, reduced production result into food scarcity/ insecurity. The victims of land conflict are therefore vulnerable to malnutrition, as result on inadequate food, which are known to affect women and children most and is a main factor for $60 \%$ death of children under five years of age [22]. More so, in the course of conflict resolution, the victims have to spent money or saving which reduces the capital investment. Sometimes, they failed to pay for family needs such as school fees for their children and some food stuffs. Reduced production also undermines potential for future growth.

In addition, certain members of households and communities have less access to regular food sources or emergency rations because they are relatively powerless as a result of their age or gender status. These include women, children, and the elderly, who are the most frequent victims of hunger in food wars, because they are left behind when active males migrate in search of food or are commandeered into military service where they are fed. Women often are forced to give up local assets (land, seeds), go without extra labour (especially of absent males), suffer lack of protection (against violence, as local community moral and social structures are destroyed), and enjoy less health care. Both women and children suffer disproportionately from illness, where malnutrition and destruction of healthcare services render them more vulnerable, especially if, in the end, they are forced to flee in search of survival.

\section{Health effects}

Table 4: Perceived effects of land -related conflicts on Health of Respondents,Field survey, 2016 Mean 2.50 and above were major effects.

\begin{tabular}{|c|c|c|}
\hline Effects on Health & Mean & SD \\
\hline Physical injuries/wounds & 3.35 & 0.662 \\
\hline Malnutrition & 3.45 & 0.638 \\
\hline Emotional trauma & 3.19 & 1.025 \\
\hline Increased hunger & 3.7 & 0.635 \\
\hline Rape/abduction of women & 3.45 & 3.45 \\
\hline Reduction in family medicare & 2.94 & 0.548 \\
\hline Increased poverty & 3.09 & 3.09 \\
\hline Increased diseases/illness & 3.16 & 0.75 \\
\hline Sexual violence/abuse & 3 & 0.627 \\
\hline Occurrence of miscarriage & 3.25 & 0.742 \\
\hline
\end{tabular}

The health effects of land-related conflicts on women farmers were as follows: occurrence of miscarriages/bleeding $(\mathrm{M}=3.25)$, physical injuries/wounds ( $M=3.45)$, emotional traumas $(M=3.19)$, 
increased hunger $(M=3.70)$, rape/abduction of women $(M=3.45)$, reduction in family medicare $(M=2.94)$, increased poverty ( $M=3.09)$, increased diseases/illness $(M=3.16)$, sexual violence/ abuse $(M=3.00)$ and malnutrition $(M=3.45)$. The narratives above are in line with the findings of Justino \& Verwimp [23] in their studies when they concluded that armed violence conflict leads to severe injuries, spread of infectious disease, and increases in permanent physical disabilities mostly among women and children. This according to them may also result in large decreases in household welfare leading to poverty. Households may also have to draw on existing savings to pay for medical bills, which will pose severe financial burden on already vulnerable households (Table 4).

\section{Psychosocial effects}

Table 5: Effects of land -related conflicts on Psychosocial Wellbeing of Respondent,Field survey, 2016, Mean=2.50 above are major effect.

\begin{tabular}{|c|c|c|}
\hline Effects on Psychosocial wellbeing & Mean & SD \\
\hline Hatred & 2.63 & 0.774 \\
\hline Humiliation & 2.83 & 0.952 \\
\hline Fear/trauma/worry & 2.57 & 0.888 \\
\hline Loss of sleep/rest & 2.98 & 0.552 \\
\hline Reduces social relationships & 2.7 & 0.545 \\
\hline Loss of education for children & 3.05 & 1.011 \\
\hline Loss of trade & 3.13 & 0.79 \\
\hline Widowhood & 2.93 & 0.916 \\
\hline Low esteem & 3.56 & 0.664 \\
\hline
\end{tabular}

Land-related conflicts also have psychosocial effects on women farmers. The following psychosocial effects were identifiedhatred $(M=2.63)$, humiliation $(M=2.83)$, fear/traumas worry $(M=2.57)$, loss of sleep/restlessness $(M=2.98)$, reduction of social relationships $(M=2.70)$, loss of education for children $(M=3.05)$ loss of trade $(M=5.13)$, widowhood $(M=2.93)$ and low esteem $(M=3.56)$. The findings of Fearon \& Laitin [24]confirms this result when they noted that most conflicts lead to killing and displacing of populations, often limiting the access of households to employment and earnings and increasing levels of instability and loss of trust. In this case the women and children are disadvantage because of the conflict since they have to move from their place of abode to a new place in search security and jobs to earn a decent living. The result of this study is consistent with that of Akresh \& de Walque [25] in their study which shows that the conflict had a negative effect on schooling outcomes of children, with exposed children completing half a year less the normal in their education. In the same vein, Shemyanika [26] study supported the findings when it was noted that conflict has negative effects on children education and presents evidence of the negative impact of armed conflict on schooling in the case of Tajikistan. Sany [27] findings also revealed that education services were also disrupted in conflict areas, where half of school-age children were deprived of education (Table 5) [28].

\section{Strategies to Cushion the Effects of Land-Related Conflicts}

Table 6: Strategies to cushion effects of land-related conflicts, Field survey, 2016 Mean=2.00 and above as major strategies.

\begin{tabular}{|c|c|c|}
\hline Strategies & Mean & SD \\
\hline Resettlement packages for victims & 2.65 & 0.662 \\
\hline Giving financial assistance to victims & 2.53 & 0.5 \\
\hline Creatingjob opportunities & 2.63 & 0.505 \\
\hline Scholarship to promote children & 2.9 & 0.503 \\
\hline education & 2.8 & 0.751 \\
\hline Provision of small scale credit facilities & 2.6 & 0.777 \\
\hline Counselling services for victims & 2.63 & 0.59 \\
\hline Land use planning & 2.64 & 0.558 \\
\hline Health facilities for rape victims & 3.62 & 0.764 \\
\hline Provision of free drugs & 2.53 & 0.627 \\
\hline Trauma healing & 2.65 & 0.806 \\
\hline Compensation for land owners & 3.67 & 0.528 \\
\hline
\end{tabular}

Table 6 showed that victims of violent land-related conflicts could be helped to manage their situations if certain provisions are put in place [29]. These provisions included resettlement packages for victims $(M=2.65)$, giving financial assistance to victims ( $M=2.53)$, creating job opportunities $(M=2.67)$, scholarship to promote children education $(\mathrm{M}=2.90)$, provision of small scale credit facilities ( $M=2.80)$, counselling services for victims $(M=2.60)$, land use planning $(\mathrm{M}=2.63)$, livelihood development programmes $(M=2.64)$, health facilities for rape victims $(M=3.62)$, provision of free drugs $(M=2.53)$, trauma healing $(M=2.65)$ and compensation for land owners (M=3.67) [30,31].

\section{Conclusion}

The most predominant form of conflicts in the study area were communal conflicts, farmer/pastoralist conflicts and farmer/ farmer conflict with grave consequences for the women farmers. The major cause of conflict was use of resource-land, water, and grasses. These conflict leads to loss of human lives, agricultural produce, illness/health problems and many more. These conflict could be managed by use of strategies such as proper land use planning, and victims helped by provision of aids in various ways.

\section{References}

1. Wehrmann B (2008) Land Conflict: A practical guide to dealing with land disputes. 
2. Yamano T, Deininger K (2005) Land Conflicts in Kenya: Causes, Impacts, and Resolutions.

3. Deininger K, Castagnini R (2006) Incidence and impact of land conflict in Uganda. Journal of Economic Behavior and Organization 60(3): 321345 .

4. Otsuka K (2006) Why can't we transform traditional agriculture in SubSaharan Africa? Review of Agricultural Economics 28(3): 332-337.

5. World Bank (2008) Uganda Post-Conflict Land Policy and Administration Options: the case of Northern Uganda.

6. Mamo H (2006) Land, Local Custom and State Policies. Land tenure, land disputes and dispute settlement among the Arsii Oromo of Southern Ethiopia, Shoukado book sellers Kamigyo, Kyoto 602, Japan.

7. Sjaastad E, Derman B, Odgaard R (2007) Conflict over Land and Water in Africa. pp. 707-711.

8. Chikaire J, Atala TK, Akpoko JG, Nnadi FN (2011) Factors influencing agricultural land use conflicts in ohaji area of Imo State, Nigeria. Report and Opinion 3(5): 7-13.

9. Best SG (2009) Protracted communal conflicts and the factors of conflict management: The Bassa- Igbirra Conflicts in Toto Local Government Area, Nasarawa State, Nigeria. pp. 47.

10. Isah MA (2012) No retreat, no surrender: conflicts for survival between fulani pastoralists and farmers in Northern Nigeria. European Scientific Journal 8(1): 331-346.

11. Gefu JO, Kolawole A (2002) Conflicts in common property resources use experience from an irrigation project.

12. Dietz AJ, Ruben R, Verhagen A (2001) Impact of climate change on Dry lands with a focus on West Africa.

13. Tarhule A, Lamb PJ (2003) Climate research and seasonal forecasting for west Africans: perceptions, dissemination, and Use? Bulletin of American Meteorological society 84(12): 1741-1759.

14. Fiki C, Lee B (2004) Conflict generation conflicts management and self organizing capabilities in drought prone rural communities in north eastern Nigeria: A Case Study. Journal of Social Development in Africa 19(2): 25-48.

15. Ajuwon SS (2004) Case study conflict in fadama communities in managing conflict in community development session 5. Community driven development. National Fadama office, Abuja. pp. 10-15.

16. Fasona MJ, Omojola AS (2005) Climate change, human security and communal clashes in Nigeria. pp. 21-23.
17. Nyong A, Fiki E (2005) Drought-related conflicts, management and resolution in west african sahel.

18. Justino P (2007) On the Links between violent conflict and household poverty: How much do we really know? MICROCON Research Working Paper 1.

19. Yahaya AB (2011) The coping mechanism of women in conflict times: A case study of Inter-ethnic conflict in Northern Ghana between Gonja on one hand and Nawuri and Konkomba on the other in East Gonja District, 1991. In International Journal of Social Sciences and Humanities Review 2(4): 1-10.

20. NPC (2006) National Census Figure. National Population Commission, Official Gazette, Abuja, Nigeria.

21. USIP (2007) Natural Resources, Conflict and Conflict Resolution. United States Institute of Peace.

22. USAID (2010) FANTA-2: The analysis of the nutrition situation in Uganda. Food and nutrition technical assistance II project (FANTA-2), Washington, DC, USA.

23. Justino P, Verwimp P (2006) Poverty dynamics, violent conflict and convergence in Rwanda. Review of Income and Wealth 59(1): 66-90.

24. Fearon J, Laitin D (2003) Ethnicity, Insurgency and Civil War. American Political Science Review 97: 75-90.

25. Akresh R, de Walque D (2008) Armed conflict and schooling: Evidence from the 1994 Rwandan Genocide 1: 47.

26. Shemyakina $O$ (2011) The effect of armed conflict on accumulation of schooling: Results from Tajikistan. Journal of Development Economics 95(2): 186-200.

27. Sany J (2010) USIP Special Report, United States Institute of Peace.

28. Peter S Hofman, N Edwin Marquart (1996) Dutch National Research Programme on Global Air pollution and climate change.

29. Elaigwu JI (2005) The management of ethno religion conflicts in Northern Nigeria. Towards a more peaceful and harmonious geo-polity. In Bobboyi H, Yakubu AM, Peace Building and Conflict Conference. Arewa House Kaduna

30. Mohamed M, Ventura S (2000) Use of geomatics for mapping and documenting indigenous tenure systems. Soc Nat Resour 13(3): 223236.

31. Okoye BC, Onyenweaku CE, Ukoha OO (2010) An ordered probit analysis of transaction cost and marketing participation small holder cassava farmer in South eastern Nigeria. Nigeria Agricultural Journal 41(2): 5-10.

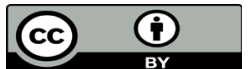

This work is licensed under Creative Commons Attribution 4.0 License

To Submit Your Article Click Here: Submit Article

DOI: 10.32474/CIACR.2018.03.000166
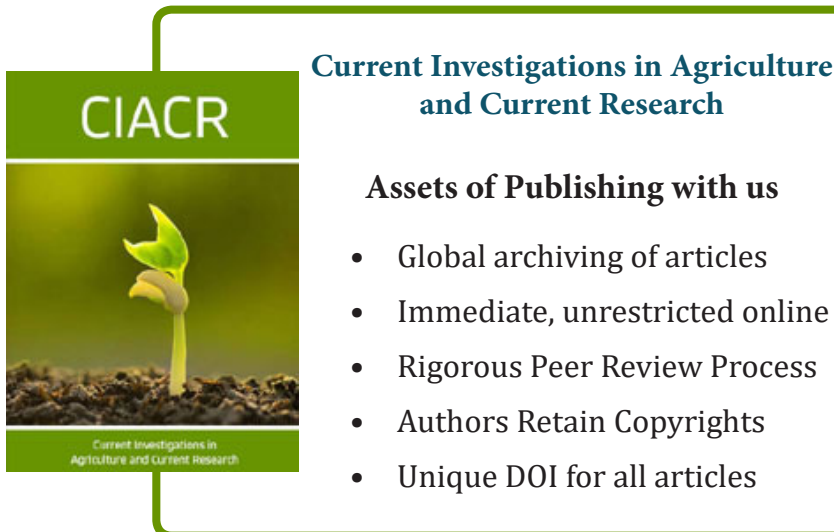

Assets of Publishing with us

- Global archiving of articles

- Immediate, unrestricted online access

- Rigorous Peer Review Process

- Authors Retain Copyrights

- Unique DOI for all articles 